\title{
BIOAVAILABILITY OF HEAVY METALS IN MANGROVE SOIL IN ALAGOAS, BRAZIL
}

\author{
BIODISPONIBILIDADE DE METAIS PESADOS EM SOLO DE MANGUE EM \\ ALAGOAS, BRASIL
}

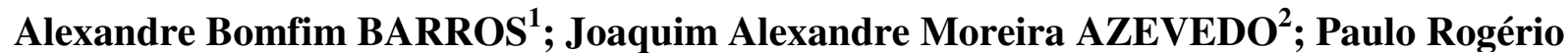
Barbosa de MIRANDA ${ }^{3}$; João Gomes da COSTA ${ }^{4}$; Velber Xavier NASCIMENTO ${ }^{5}$

1. Geógrafo, Mestre em Análise de Sistemas Ambientais, Professor e Pesquisador do Instituto Federal de Alagoas - IFAL, Alagoas, Brasil.alexandrebarros_tm@ hotmail.com; 2. Licenciado em Geografia, Professor Mestre do Instituto Federal de Alagoas - IFAL, Alagoas, Brasil. jazevedo951@gmail.com; 3. Químico, Professor Doutor do Programa de Pós-graduação em Análise de Sistemas Ambientais - PPGASA, Centro Universitário CESMAC, Alagoas, Brasil. oluap81@ gmail.com; 4. Engenheiro Agrônomo, Professor Doutor do Programa de Pós-graduação em Análise de Sistemas Ambientais - PPGASA, Centro Universitário CESMAC, Brasil, joo.gomesdacosta@gmail.com; 5. Biólogo, Professor Doutor do Programa de Pós-graduação em Análise de Sistemas Ambientais PPGASA, Centro Universitário CESMAC, Alagoas, Brasil. velberxavier@ gmail.com
\end{abstract}

\begin{abstract}
The mangrove forest is an important transitional ecosystem consisted of terrestrial and marine environment located in tropical and subtropical regions with average temperatures above $20{ }^{\circ} \mathrm{C}$. In Alagoas, the mangrove forests are found on the entire coastline from Maragogi to Piaçabuçu. In the last 20 years, due to the pollution of water resources, studies of coastal aquatic ecosystems have been developed. The objective of this study was to analyze the physicochemical properties and determine the levels of heavy metals in mangrove sediments of the Mundaú-Manguaba estuary lagoon complex (MMELC) and Meirim River in Alagoas. Zinc, copper, lead, cadmium and chromium were chosen due to their relationship with sewer, agricultural, and industrial wastes. 22 soil samples were collected in the MMELC and in the Meirim River. The samples were submitted to soil routine analyses of Embrapa. The heavy metals were extracted by the Mehlich-1 method and analyzed by atomic absorption spectrometry. The mean concentrations of these metals in the sediment samples followed the order $\mathrm{Mn}>\mathrm{Zn}>\mathrm{Pb}>\mathrm{Cr}>\mathrm{Cu}>\mathrm{Cd}$ in MMELC and $\mathrm{Zn}>\mathrm{Mn}>\mathrm{Pb}>\mathrm{Cr}>\mathrm{Cu}>\mathrm{Cd}$ in Meirim River. All proposed heavy metals were found in sediments, however, the cadmium levels were above the normal levels proposed by Environment National Council (CONAMA) and Canadian Council of Ministers of the Environment. The study shows that the analysis of sediment can contribute to environmental monitoring actions and development of public policies aimed to controlling the sustainable use of natural resources of the studied areas.
\end{abstract}

KEYWORDS: Contamination. Heavy metal. Mangrove.

\section{INTRODUCTION}

The mangrove forest is an important transitional ecosystem between terrestrial and marine environment, located in the mouth of Rivers and estuaries of tropical and subtropical areas with flooded soil by the tidal cycle and having wide range of salinity. It has vegetation composed of various halophile species. (SPALDING et al., 2010).

With the presence of a predominantly tropical area, Brazilian territory has a lot of mangrove forests present. This justifies the great quantity of fish species on the Brazilian coast. The mangroves in the State of Alagoas are found along the entire coastal belt (CORREIA; SOVIERZOSKI, 2005).

The main characteristics of mangrove soils have high salt content and organic matter, low consistency, anoxic conditions, dark gray coloration, and textures ranging from silty to sandy (EMBRAPA, 2011).

According to Moreira (2014) in the past 20 years, the pollution of water resources has led to the collapse of coastal aquatic ecosystems which are important for preservation and the balance of life. The industrial and urban wastes released in these ecosystems have been subject of discussion because they cause environmental changes and increase pressure on coastal areas.

Among the contaminants from industrial, agricultural, and urban wastes, heavy metals stand out because they are non biodegradable. The metals introduced by human activities often exceed the natural levels and represents a risk to human and animal health (PRIETO et. Al., 2008). The bioaccumulation of metals by organisms can have diversified effects for various trophic levels of the food chain. This effect culminates with the 
occurrence of higher contamination rates in the higher levels of the trophic web (SILVA, 2015).

Soil attributes can express the conditions for the preservation or degradation of mangroves. These conditions are directly related to the degree of development and distribution of plant species (THUONG el at. 2013). In this way, the study of soil physicochemical characteristics and the evaluation of its contamination by heavy metals are important tools for measuring the environmental health conditions. They can help in the planning of preservation, conservation, and recovery actions of degraded areas and subsidize the studies related to the risk that they pose to humans' health. The objective of this study was to evaluate the physicochemical properties and determine the levels of heavy metals in mangrove sediments of the Mundaú-Manguaba estuary lagoon complex (MMELC) and Meirim River in Alagoas.

\section{MATERIAL AND METHODS}

\section{Studied area}

Two mangrove forest areas were chosen in metropolitan region of Maceió. The first studied area is located at the Mundaú-Manguaba estuary lagoon complex (MMELC) (9 69"66'S and $35^{\circ} 78^{\prime \prime} 57.87^{\prime} \mathrm{W}$ ) (Figure 1). The second area is located near the mouth of the Meirim River (9³0"26' S and 35'37'14'W) (Figure 2).
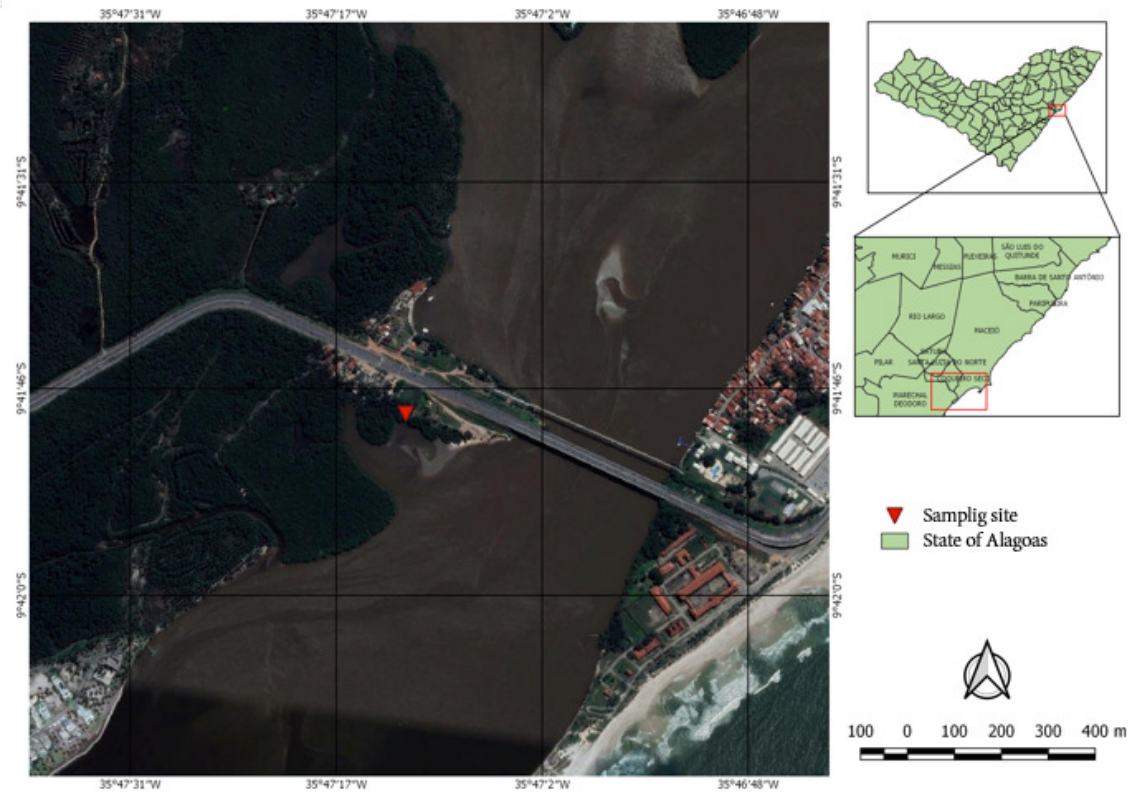

Figure 1. Map displaying the study area and sampling site in the MMELC.
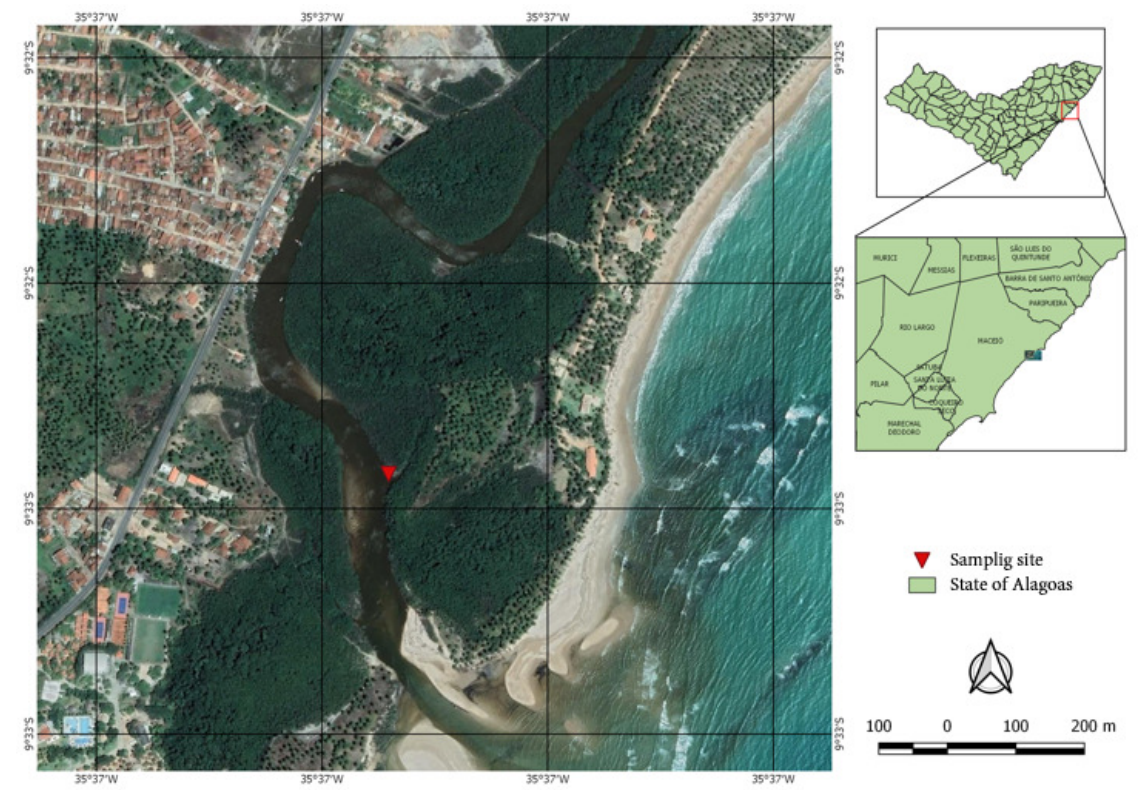

Figure 2. Map displaying the study area and sampling site in the Meirim River. 


\section{Sample collection}

Samples were collected at 9 different points at low tide between March to November in 2017 and followed the steps described by Embrapa (2011) with adaptations. The soil samples were collected in a zig-zag pattern with 100 transverse meters and 2 meters from the border with different flood degrees. Each point was located 10 meters away from another. The samples had an approximate weight of $500 \mathrm{~g}$ and collected using a Dutch Auger soil sampler.

\section{Physical-Chemical Analysis}

The soil sample analysis followed the steps described by Embrapa (2011) with adaptations. The samples were dried in a drying oven at $40{ }^{\circ} \mathrm{C}$ for 24 hours. The smashing was carried out using a wooden roller. Smashed samples were passed through a 20 and $2 \mathrm{~mm}$ sieves. Granulometric analysis was performed by wet system using sodium hydroxide $1 \mathrm{M}$ as dispersing agent and characterized as sand, silt, and clay (EMBRAPA, 2011). The sand fraction was characterized as coarse and fine sand and the clay fraction was characterized using the pipette method. The organic matter levels were obtained by wet system with potassium dichromate in sulfuric acid media. (EMBRAPA, 2011). The soil $\mathrm{pH} \quad \mathrm{H}_{2} \mathrm{O}$ was verified using a combined electrode immersed in a soil/liquid suspension.

\section{Heavy Metals Extraction}

BARROS, A. B. et al

Heavy metals were extracted by the Mehlich-1 method, with sulfuric and chloridric acid at the 1:10 ratio (soil:solution) and quantified by atomic absorption spectrometer model novA A300 (Analytik Jena).

\section{Soil content evaluation}

The content of mangrove soil with heavy metal levels was evaluated according to Canadian Council of Ministers of the Environment (CCME, 2012) and Resolution 344 of Environment National Council (CONAMA 344/04) (CONAMA, 2004).

With the objective of determining reference values for heavy metals in sediments, the Canadian Council of Ministers of the Environment developed the Canadian Sediment quality guidelines as protective tools to support the function of healthy aquatic ecosystems. They are based on field research programs that have demonstrated associations between chemicals and biological effects by establishing cause and effect relationships in particular organisms. (CCME, 2012). The Threshold Effect Level (TEL), and Probable Effect Level (PEL) represent the minimum and maximum probability of occurrence of harmful effects over biota. Concentrations values under TEL index indicates that adverse effects are rarely expected and concentrations values over PEL index indicates that adverse effects are expected. The range from TEL to PEL are the values where occasionally can occur such effects (table 1) (CCME, 2012).

Table 1. TEL index (Threshold Effect Level) and PEL index (Probable Effect Level) in $\mathrm{mg} \mathrm{kg}^{-1}$ (CCME, 2012).

\begin{tabular}{lll}
\hline Metals & TEL & PEL \\
\hline Arsenic & 7.24 & 41.6 \\
Cadmium & 0.7 & 4.2 \\
Chromium & 52.3 & 160 \\
Copper & 18.7 & 108 \\
Lead & 30.2 & 112 \\
Mercury & 0.13 & 0.7 \\
Zinc & 124 & 271 \\
\hline
\end{tabular}

\section{Statistics}

Statistical analysis was carried out using Genes program (CRUZ, 2013). The obtained data were submitted to variance analysis and the mean values were compared using the Fisher's LSD test with $5 \%$ of probability.

\section{RESULTS AND DISCUSSION}

\section{Soil Texture, $\mathrm{pH}$ and Organic Matter}

The average percentage of sand, silt, and clay has changed in the two studied estuaries. In the
MMELC, the mean values of sand, clay, and silt were $624.3 \mathrm{~g} \mathrm{~kg}^{-1}, 273 \mathrm{~g} \mathrm{~kg}^{-1}$ and $102.64 \mathrm{~g} \mathrm{~kg}^{-1}$ of soil respectively which corresponds to $65 \%$ of sand, $25 \%$ of clay and $10 \%$ of silt. At the mouth of the Meirim River, the results were very similar to those of the MMELC. The mean values of sand, clay, and silt were $597.5 \mathrm{~g} \mathrm{~kg}^{-1}, 287.6 \mathrm{~g} \mathrm{~kg}^{-1} 115.5 \mathrm{~g} \mathrm{~kg}^{-1}$ of soil which corresponds to $60 \%$ sand, $29 \%$ clay and $11 \%$ silt.

The high sand content values and low quantities of clay in soil samples of the two estuaries being studied are a result of their proximity 
to the ocean. These parameters are very important for studies of environmental pollution from heavy metals. Mangroves with low hydrodynamic energy present highest amounts of clay and heavy metals (REITERMAJER et al. 2011) which can contribute to a higher adsorption of these metals in soil.

Reitermajer et al. (2011) and Silva (2015) observed the relationship between clay and silt with the heavy metals and their adsorption with fine particles. This should not occur with the MMELC's and the Meirim's soils because of their sandy profile. This condition was also observed by Nayar et al. (2006) and Prasad and Ramanatham (2008).

The amount of organic matter in soil samples of the MMELC and the Meirin River presented a high variation of $0.92 \%$ to $3.37 \%$ of soil (mean of $2.02 \%$ ) and $1,04 \%$ to $23,27 \%$ of soil (mean of 6,84\%) respectively.

Sediments with values greater than $10 \%$ are considered organic soils and lower than $10 \%$ are considered inorganic or mineral soils. Thus, the soil samples of this study are considered inorganic. In according to Cantarella et al. (1992), higher levels of heavy metals in the soil are also provoked by higher amounts of organic matter, once these metals can be adsorbed in organic matter colloid particles decrease its bioavailability. The soils of the MMELC and the Meirim River presented a sandy profile and lower organic matter level and, therefore, a lower adsorption capacity of heavy metals increase their bioavailability.

The amount of O.M. found in this study is in the same range as the determinations from Corrêa et al. (2012) on River sediments from Bacanga and the Anil River are lower to those reported by Da
Silva et al., (2014) who analyzed mangrove sediments in the Tibiri River.

The $\mathrm{pH}$ values in the two estuaries indicated a healthy soil environment. The sediments of the MMELC and the Meirim River showed a slightly alkaline $\mathrm{pH}$ mean of 7.4 and 8.1, respectively. These results are very similar to those found in other works such as Silva (2015), who studied the Parnaíba basin estuary soils, with $\mathrm{pH}$ ranging from 6.5 to 8.5 and Wang et al. (2016), in your study of mangrove forest of China National Reserve, where detected the $\mathrm{pH}$ of soils ranging from 5.99 to 8.26, averaging 7.53.

\section{Heavy metal levels}

Table 2 shows the mean values of heavy metal levels detected in the soils from the MMELC and the Meirim River. Generally, the concentrations of $\mathrm{Cu}, \mathrm{Zn}, \mathrm{Cd}, \mathrm{Cr}, \mathrm{Pb}$ and $\mathrm{Mn}$ in MMELC ranged from 0.89 to $1.09,5.31-7.95,0.01-0.17,0.71-1.79$, 2.09-5.46, and 7.03-15.31 mg kg-1 dry weight, respectively. In the Meirim River the concentrations ranged from 0.32 to $2.48,4.15-12.14,0.01-0.68$, $0.6-2.22$, $1.09-5.66$, and $0.96-5.84 \mathrm{mg} \mathrm{kg}{ }^{-1}$ dry weight. The mean concentrations of these metals in the sediment samples followed the order $\mathrm{Mn}>\mathrm{Zn}$ $>\mathrm{Pb}>\mathrm{Cr}>\mathrm{Cu}>\mathrm{Cd}$ in the MMELC and $\mathrm{Zn}>\mathrm{Mn}$ $>\mathrm{Pb}>\mathrm{Cr}>\mathrm{Cu}>\mathrm{Cd}$ in the Meirim River.

According to table 2, manganese and zinc showed the highest averages while cadmium presented the lowest average. Similar results were found by Liyuan et al. (2016) and Wang et al. (2016). Different results were found by Chai et al. (2016) (1805, 443 and $13.6 \mathrm{mg} \mathrm{kg}-1$ of $\mathrm{Mn}, \mathrm{Zn}$ and $\mathrm{Cd}$ respectively) and similar results were found by Wang et al. (2016) $(\mathrm{Cd}=0,07 \mathrm{mg} \mathrm{kg}-1)$.

Table 02. Comparison between heavy metal concentrations of MMELC and Meirim River ( $\left.\mathrm{mg} \mathrm{kg}^{-1}\right)$

\begin{tabular}{lll}
\hline Metals & MMELC & Meirim River \\
\hline $\mathbf{C u}$ & $1.0 \pm 0.07$ & $1.05 \pm 0.71$ \\
$\mathbf{Z n}$ & $6.55 \pm 0.94$ & $8.58 \pm 2.62$ \\
$\mathbf{C d}$ & $0.04 \pm 0.05$ & $0.20 \pm 0.24$ \\
$\mathbf{C r}$ & $1.29 \pm 0.37$ & $1.38 \pm 0.71$ \\
$\mathbf{P b}$ & $3.86 \pm 1.05$ & $3.69 \pm 1.37$ \\
$\mathbf{M n}$ & $10.02 \pm 2.95$ & $3.81 \pm 1.92$ \\
\hline
\end{tabular}

Copper was detected in the MMELC (1.0 $\left.\mathrm{mg} \mathrm{kg}^{-1}\right)$ and the Meirim River $\left(1.05 \mathrm{mg} \mathrm{kg}^{-1}\right)$. Both sediments did not present indicative values of possible effects on the biological community and are below the values found by Wang et al. (2016) in China.
Zinc was detected in the MMELC sediments
ranging from $5.31 \mathrm{mg} \mathrm{kg}^{-1}$ to $7.95 \mathrm{mg} \mathrm{kg}{ }^{-1}\left(6.55 \mathrm{mg} \mathrm{kg}^{-1}\right)$. The Meirim River presented a wide variation ranging from $4.15 \mathrm{mg} \mathrm{kg}^{-}$ ${ }_{1}^{1}$ to $12.14 \mathrm{mg} \mathrm{kg}^{-1}$ (mean of $8.58 \mathrm{mg} \mathrm{kg}^{-1}$ ). The mean values of zinc in the two estuaries did not present significant indexes of contamination using TEL and 
PEL reference values and CONAMA resolution 344/04 (CCME 2012; CONAMA, 2013). These results are in accordance with Zhenglei et al. (2014) in the estuary of the Yellow River delta $(54.82 \mathrm{mg}$ $\mathrm{kg}^{-1}$ ), Thuong et al. (2013) in the Lich estuary in Vietnam (459 $\mathrm{mg} \mathrm{kg}^{-1}$ ), and Coimbra et al. (2015) in the Maracaípe River (ranging from $5.9 \mathrm{mg} \mathrm{kg}^{-1}$ to $281.0 \mathrm{mg} \mathrm{kg}^{-1}$ ).

Lead was detected in the MMELC soil samples ranging from $2.09 \mathrm{mg} \mathrm{kg}^{-1}$ to $5.46 \mathrm{mg} \mathrm{kg}^{-1}$ (mean of $3.86 \mathrm{mg} \mathrm{kg}^{-1}$ ) and the Meirim River showed lead concentrations between $1.09 \mathrm{mg} \mathrm{kg}^{-1}$ to $5.66 \mathrm{mg} \mathrm{kg}^{-1}$ (mean of $3.69 \mathrm{mg} \mathrm{kg}^{-1}$ ). These results did not present significant differences between the two studied estuaries. It was verified that the values of these two environments are lower than the dangerous limits found in other works like Quináia et al. (2009) (ranging from 7 to $320 \mathrm{mg} \mathrm{kg}^{-}$ $\left.{ }^{1}\right)$ and Wang et al. (2016) $\left(\mathrm{Pb}=44.02 \mathrm{mg} \mathrm{kg}^{-1}\right)$.

Results for chromium showed low values for both studied estuaries. The results of the MMELC showed a range from $0.71 \mathrm{mg} \mathrm{kg}-1$ to 1.79 mg kg-1 (mean of $1.29 \mathrm{~m} \mathrm{~kg}-1$ ). The sediments from the Meirim River showed results ranging from $0.48 \mathrm{mg} \mathrm{kg}-1$ to $2.4 \mathrm{mg} \mathrm{kg}-1$ (mean of $1.38 \mathrm{mg} \mathrm{kg}$ 1). The heavy metal sediment levels of the MMELC and the Meirim River are lower than the dangerous limits described by CCME and CONAMA. Other

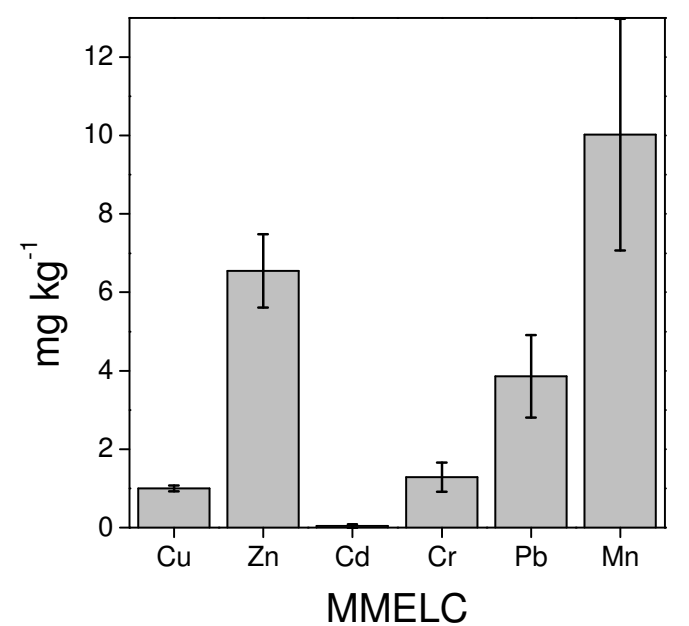

BARROS, A. B. et al

works showed higher concentrations of chromium like Wang et al. (2016) (mean of $30.43 \mathrm{mg} \mathrm{kg}-1$ ) and Chai et al. (2017) (mean of $44.02 \mathrm{mg} \mathrm{kg}-1$ ).

Cadmium was detected in the soil samples of the MMELC and the Meirim River between 0.01 $\mathrm{mg} \mathrm{kg}^{-1}$ to $0.17 \mathrm{mg} \mathrm{kg}^{-1}$ (mean of $0.04 \mathrm{mg} \mathrm{kg}^{-1}$ ) and $0.01 \mathrm{mg} \mathrm{kg}^{-1}$ to $0.68 \mathrm{~g} \mathrm{~kg}^{-1}$ (mean of $0.21 \mathrm{mg} \mathrm{kg}^{-1}$ ), respectively. These results show that the cadmium indexes in the MMELC sediments are lower than the dangerous limits described by CCME and CONAMA. Cadmium is easily absorbed in sediments with alkaline $\mathrm{pH}$ values, therefore, the high concentrations of cadmium are due the $\mathrm{pH}$ values found in the Meirim River estuary (7.4 to 8.4) (SILVA, 2002).

In the soils from MMELC and Meirim river there is a high concentration of sand $(63 \%$ and $60 \%$, respectively). Sand is a sedimentary rock; therefore, the normal cadmium levels should not exceed $0.3 \mathrm{mg} \mathrm{kg}^{-1}$, thus, the contamination indexes are considered low but are already worrying, especially in the Meirim River.

Only manganese levels showed a significant difference $(\mathrm{p}<0.001)$ between the two studied estuaries (Figure 3). This can be related to anthropic sources like sewage, industries, fertilizers and other solid wastes.

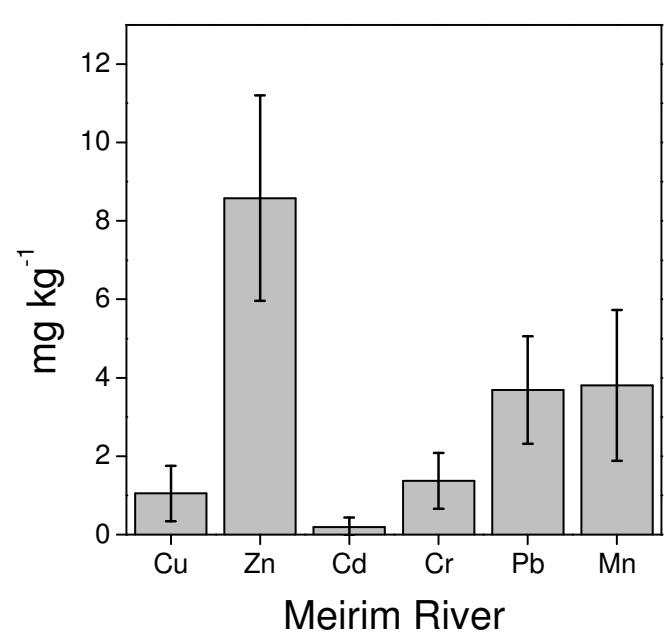

Figure 3. Concentration (mean \pm standard deviation) of metals with two mangrove regions - MMELC and Meirim river (dry mass concentration measured in $\mathrm{mg} \cdot \mathrm{kg}^{-1}$ ).

\section{CONCLUSIONS}

It has been observed a relative granulometric homogeneity in sediments of MMELC and Meirim River. Both estuaries have a large amount of sand, higher than $60 \%$ of the soil content. In addition, the two studied estuaries presented a slightly alkaline $\mathrm{pH}$.
All heavy metals were detected at acceptable concentrations limits to the biotic community.

This work can contribute for to environmental monitoring actions and development of public policies aimed to controlling the sustainable use of natural resources of the studied areas. 
RESUMO: O manguezal é um importante ecossistema de transição entre o ambiente marinho e terrestre, localizado em regiões tropicais e subtropicais com temperaturas médias acima de $20^{\circ} \mathrm{C}$. Em Alagoas podemos encontrar florestas de mangue em praticamente todo o litoral desde Maragogi até Piaçabuçu. Nos últimos 20 anos, a poluição dos recursos hídricos tem levado ao estudo dos ecossistemas aquáticos costeiros, que são importantes para preservação e equilíbrio da vida. O objetivo deste trabalho foi analisar as propriedades físico-químicas e determinar os teores ambientalmente disponíveis de metais nos sedimentos do mangue existente na foz CELMM (e do rio Meirim em Alagoas. Foram escolhidos os metais zinco, cobre, chumbo, cádmio e crômio por estarem ligados aos despejos de esgotos, projetos agropecuários, e fontes industriais. Foram coletadas 22 amostras de solo nos estuários do CELMM e do rio Meirim. As amostras foram submetidas as análises de rotina para solos da Embrapa. As concentrações médias desses metais nas amostras de sedimento seguiram a ordem $\mathrm{Mn}>\mathrm{Zn}>\mathrm{Pb}>\mathrm{Cr}>\mathrm{Cu}>\mathrm{Cd}$ in CELMM e $\mathrm{Zn}>\mathrm{Mn}>\mathrm{Pb}>\mathrm{Cr}>\mathrm{Cu}>\mathrm{Cd}$ no Rio Meirim. Os metais foram extraídos pelo método Mehlich-1 e analisados por meio de espectrometria de absorção atômica. Foram encontrados nos sedimentos todos os metais propostos na pesquisa com destaque para os teores de cádmio detectados em valores absolutos acima de valores considerados normais pelo Conselho Nacional do Meio Ambiente e pelo Canadian Council of Ministers of the Environment em alguns pontos do estuário do rio Meirim. O estudo mostra que a análise dos sedimentos pode, portanto, contribuir para ações de monitoramento ambiental, subsidiando a implantação e desenvolvimento de políticas públicas que visem controlar o uso racional e sustentável dos recursos naturais das áreas do estudas.

PALAVRAS CHAVE: Contaminação. Manguezal. Metais peados.

\section{REFERENCES}

CANTARELla, H.; ABREU, C. Aparecida; BERTON, R. S. Fornecimento de nutrientes pela matéria orgânica. In: GUERRINI, I. A. (Ed.) Encontro sobre matéria orgânica do solo: problemas e soluções. Botucatu: Faculdade de Ciências Agronômicas, 1992. p. 63-122.

CCME - Canadian Council of Ministers of the Environment (2012). Disponível em: <http://ceqgrcqe.ccme.ca>. Access in 13 ago. 2017.

CHAI, L.; Li, H.; YANG, Z.; MIN, X.; LIAO, Q.; LIU, Y. Heavy metals and metalloids in the surface sediments of the Xiangjiang River, Hunan, China: distribution, contamination, and ecological risk assessment. Environmental Science and Pollution Research, v. 24, n. 1, p. 874-885, 2017. https://doi.org/10.1007/s11356-016-7872-x

COIMBRA, C. D; CARVALHO, G.; PHILIPPINI, H.; SILVA, M. F. M.; NEIVA, E. Determinação a concentração de metais traço em sedimentos do Estuário do Rio Maracaípe - Pe/Brasil. Brazilian Journal of Aquatic Science and Technology Univali - 2015. https://doi.org/10.14210/bjast.v19n2.4863

CONAMA, 2013 - Conselho Nacional do Meio Ambiente. Resolução número 460/2013. Disponível em: http//www.mma.gov.br. Access in 05 out 2017.

CORRÊA, L. B. Distribuição e fracionamento de metais traço nos sedimentos dos rios Anil e Bacanga, São Luís - MA. 2012. p. 82. Dissertação (Mestrado em Química) Departamento de Química, Universidade Federal do Maranhão, São Luís, 2012.

CORREIA, M. D.; SOVIERZOSKI, H. H. Ecossistemas marinhos: recifes, praias e manguezais. EdUFAL. Maceió-AL 2005.

CRUZ, C. D. GENES - a software package for analysis in experimental statistics and quantitative genetics. Acta Scientiarum. Agronomy, Maringá, v.35, p.271-276, 2013. 
SILVA, G. S.; NASCIMENTO, A. S.; DE SOUSA, E. R.; MARQUES, E. P.; BRANDÃO, A. L. M.; CORRÊA, L. B; SILVA, G. S. Distribution and Fractionation of Metals in Mangrove Sediment from the Tibiri River Estuary on Maranhão Island, Amazon Region. Rev. Virtual Química, v. 6, n. 2, p. 323-336, 2014. https://doi.org/10.5935/1984-6835.20140023

EMPRESA BRASILEIRA DE PESQUISA AGROPECUÁRIA. Manual de métodos de análise de solo. 2. Ed Revisada. Rio de Janeiro, 2011.

MOREIRA, C. C. L. Valores de referência de qualidade para metais pesados em solos de mangue do Estado do Ceará: subsídios para gestão da zona costeira. 2014 Tese (Doutorado) - Departamento de Geografia, Programa de Pós-Graduação em Geografia, Universidade Federal do Ceará, Fortaleza, 2014.

NAYAR, S.; MILLER, D. J.; HUNT, A.; GOH, B. P. L. Environmental effects of dredging on sediment nutrients, carbon and granulometry in a tropical estuary. Environmental Monitoring and Assessment, v. 127, pág. 1-13, 2006. https://doi.org/10.1007/s10661-006-9253-2

PRASAD, M. B. K.; RAMANATHAN, A. L. Sedimentary nutrient dynamics in a tropical estuarine mangrove ecosystem. Estuarine, Coastal and Shelf Science, v. 80, n. 1, p. 60-66, 2008.

https://doi.org/10.1016/j.ecss.2008.07.004

PRIETO, A. Levels and spatial distribution of inorganic and organic contaminants in sediments along the Bilbao estuary. Marine Pollution Bulletin. 2008. https://doi.org/10.1016/j.marpolbul.2008.08.027

QUINÁIA, SP; CAVAGNOLI, AR \& Martins, VJ. Avaliação da Distribuição de Cr, $\mathrm{Pb}$ e Cu em Sedimentos Superficiais. Revista Ciências Exatas e Naturais, v. 11, n. 1, 50-66, 2009.

REITERMAJER, D.; CELINO, J. J.; QUEIROZ, A. F. S. Heavy metal distribution in the sediment profiles of the Sauípe River Estuary, north seashore of the Bahia State, Brazil. Microchemical Journal, 99: 400-405, 2011. https://doi.org/10.1016/j.microc.2011.06.015

SILVA, M. R. C. Estudo de sedimentos da bacia hidrográfica do Moji-Guaçu, com ênfase na determinação de metais. 2002. Dissertação (Mestrado em Química Analítica) - Instituto de Química de São Carlos, Universidade de São Paulo, São Carlos, 2002.

SILVA, W. M. Metais pesados em solos de manguezais em estuários da bacia Paraíba, Nordeste do Brasil. 2015, Dissertação de mestrado em Ciências do Solo. Departamento de Agronomia, Universidade Federal Rural de Pernambuco, Recife, 2015.

SPALDING, M.; KAINUMA, M.; COLLINS, L. World Atlas of Mangrove. London: Earthscan Publications. 336 p. 2010.

SU, Y.; YANG, R. Background concentrations of elements in surface soils and their changes as affected by agriculture use in the desert-oasis ecotone in the middle of Heihe River Basin, North-west China. J. Geochem. Explor., 98:57-64, 2008. https://doi.org/10.1016/j.gexplo.2007.12.001

THUONG, N. T.; YONEDA, M.; IKEGAMI, M.; TAKAKURA, M. Source discrimination of heavy metals in sediment and water of To Lich River in Hanoi City using multivariate statistical approaches. Springer Science+Business Media Dordrecht 2013. https://doi.org/10.1007/s10661-013-3155-x

WANG, J.; DU, H.; XU, Y.; CHEN, K.; LIANG, J.; KE, H.; CHENG, S.; LIU, M.; DENG, H.; HE, T.; WANG, W.; CAI, M. Environmental and Ecological Risk Assessment of Trace Metal Contamination in Mangrove Ecosystems: A Case from Zhangjiangkou Mangrove National Nature Reserve, China. Hindawi Publishing Corporation BioMed Research International. 2016. https://doi.org/10.1155/2016/2167053 
Bioavailability of heavy metals...

BARROS, A. B. et al

ZHENGLEI, X.; ZHIGAO, S.; ZHANG, H.; ZHAI, J. Contamination assessment of arsenic and heavy metals in a typical abandoned estuary wetland a case study of the Yellow River Delta Natural Reserve. Springer International Publishing Switzerland 2014. 